\title{
Soil carbon sequestration and land-use change: processes and potential
}

\author{
W. M. POST* and K. C. KWON \\ * Environmental Sciences Division, Oak Ridge National Laboratory, Oak Ridge, TN 37831-6335, USA, +Chemical Engineering \\ Department, Tuskeegee University, Tuskeegee, AL 36088, USA
}

\begin{abstract}
When agricultural land is no longer used for cultivation and allowed to revert to natural vegetation or replanted to perennial vegetation, soil organic carbon can accumulate. This accumulation process essentially reverses some of the effects responsible for soil organic carbon losses from when the land was converted from perennial vegetation. We discuss the essential elements of what is known about soil organic matter dynamics that may result in enhanced soil carbon sequestration with changes in land-use and soil management. We review literature that reports changes in soil organic carbon after changes in land-use that favour carbon accumulation. This data summary provides a guide to approximate rates of SOC sequestration that are possible with management, and indicates the relative importance of some factors that influence the rates of organic carbon sequestration in soil. There is a large variation in the length of time for and the rate at which carbon may accumulate in soil, related to the productivity of the recovering vegetation, physical and biological conditions in the soil, and the past history of soil organic carbon inputs and physical disturbance. Maximum rates of $C$ accumulation during the early aggrading stage of perennial vegetation growth, while substantial, are usually much less than $100 \mathrm{~g} \mathrm{C} \mathrm{m}^{-2} \mathrm{y}^{-1}$. Average rates of accumulation are similar for forest or grassland establishment: $33.8 \mathrm{~g} \mathrm{C} \mathrm{m}^{-2} \mathrm{y}^{-1}$ and $33.2 \mathrm{~g} \mathrm{C} \mathrm{m}^{-2} \mathrm{y}^{-1}$, respectively. These observed rates of soil organic $\mathrm{C}$ accumulation, when combined with the small amount of land area involved, are insufficient to account for a significant fraction of the missing $C$ in the global carbon cycle as accumulating in the soils of formerly agricultural land.
\end{abstract}

Keywords: carbon sequestration, land-use, reforestation, soil carbon

Received 2 June 1999; resubmitted and accepted 6 August 1999

\section{Introduction}

Soil organic carbon pools

In terrestrial ecosystems the amount of carbon in soil is usually greater than the amount in living vegetation. It is therefore important to understand the dynamics of soil carbon as well as its role in terrestrial ecosystem carbon balance and the global carbon cycle. The loss of soil organic carbon by conversion of natural vegetation to cultivated use is well known. Various land uses result in very rapid declines in soil organic matter (Jenny 1941; Schlesinger 1985; Mann 1986; Post \& Mann 1990; Davidson \& Ackerman 1993). Much of this loss in soil

Correspondence: W. M. Post, tel. +1/865-576-3431, fax: +1/865574-2232, e-mail: wmp@ornl.gov organic carbon can be attributed to reduced inputs of organic matter, increased decomposability of crop residues, and tillage effects that decrease the amount of physical protection to decomposition. Herein we assemble information concerning processes that regulate the amount and rate of change in SOC, and use this information to interpret measurements of SOC accumulation when a soil is no longer cultivated and returns to supporting perennial vegetation.

Soil organic carbon includes plant, animal and microbial residues in all stages of decomposition. Many organic compounds in the soil are intimately associated with inorganic soil particles. The turnover rate of the different soil organic carbon compounds varies due to the complex interactions between biological, chemical, 
and physical processes in soil. Although there may be a continuum of soil organic carbon compounds in terms of their decomposability and turnover time, physical fractionation techniques are often used to define and delineate various relatively discrete soil organic carbon pools. Physically defined fractions, while containing a diverse array of organic compounds, integrate structural and functional properties of soil organic carbon (Christensen 1996). Physical fractionation of soil emphasizes the role of soil minerals and soil structure in SOC turnover, and relates more directly to SOC dynamics in situ than classical wet chemical SOC fractions (Elliott \& Cambardella 1991; Christensen 1992; Oades 1993). Figure 1 shows an outline of major physically separated SOC fractions that correspond to pools in many soil carbon turnover models used to simulate long-term (decades to centuries) changes in soil carbon (Christensen 1996; Buyanovsky et al. 1994).

The light fraction organic carbon (LF-OC) is free (not complexed with mineral matter), particulate plant and animal residues undergoing decomposition (Spycher et al. 1983). Occasionally some of this material may be biologically resistant, such as charcoal (Skjemstad et al. 1990). Part of the LF-OC can be physically stabilized in macroaggregates as intra-aggregate particulate carbon (Cambardella \& Elliot 1992, 1993). Thick surface accumulations of LF-OC occur in boreal and tundra ecosystems where it persists due to low temperatures slowing decomposition. In ecosystems that are more commonly used for cultivation, accumulation of LF-OC can be quite high despite higher decomposition rates where there are significant returns of plant litter (forests and permanent grasslands). This fraction is highly decomposable and can show seasonal fluctuations and spatial variation with changes in litter inputs (Boone 1994). The turnover of LF$\mathrm{OC}$ in such ecosystems is linked to macroaggregate formation and its amount is greatly impacted by cropping and tillage (Beare et al. 1994; Biederbeck et al. 1994; Bremer et al. 1994). Short-term shifts in SOC storage and turnover are in large part due to the dynamic nature of this pool which has a bulk turnover time measured in months to a few years.

SOC is transformed by bacterial action and stabilized in clay- or silt-sized organomineral complexes (HF-OC) where the majority of SOC is found (Fig. 1). The highest concentrations of SOC are associated with $<5 \mu \mathrm{m}$ mineral particles. Following the addition of simple substrates, new SOC is found to be associated with a range of mineral particle sizes. However, clay-sized organomineral complexes often show greater accumulations and subsequently more rapid loss rates than in silt-sized particles, indicating a higher stability of silt-SOC (Christensen 1996). Turnover times of the HF-OC are on the order of decades.

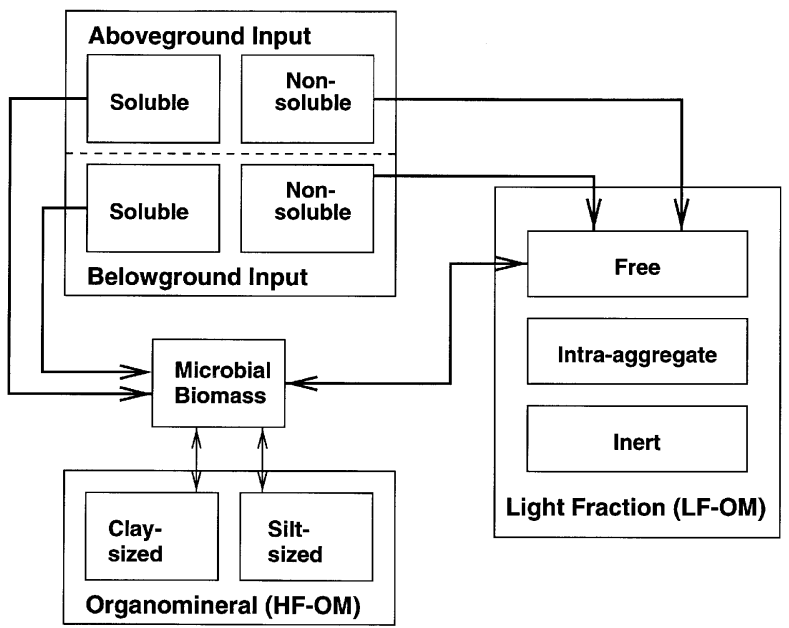

Fig. 1 Mineralization and transfer of organic matter in soil (Christensen 1996).

Although a small portion of SOC, microbial biomass mediates the transfer of SOC among inputs, LF-OC and organomineral HF-OC. As a result, rates of transfer and transformation are influenced by biologically important factors including soil moisture and soil temperature. In addition, most models of SOC turnover postulate a pool of passive (old or stable) carbon with turnover times of 1500-3500 years or longer (Parton et al. 1988; Jenkinson 1990). The presence of such a pool with long turnover is necessary for consistency with ${ }^{14} \mathrm{C}$ measurements (Harrison et al. 1993). This pool is not explicitly shown in Fig. 1, since a physical method of isolating this passive SOC fraction is unknown. It is thought that passive SOC is comprised of a nearly inert LF-OC component, say charcoal, and some very chemically recalcitrant material in organomineral HF-OC complexes.

The amount, decomposability (represented in Fig. 1 as proportions of soluble and nonsoluble components), and placement of above-ground and below-ground inputs differ greatly between ecosystem types and with landuse. In agricultural soils above-ground inputs and most roots are mechanically mixed in the surface layer. In permanently vegetated soils, above-ground residues are left on the surface to decompose or a portion may be transported or mixed into the soil by animal activity. Roots and root exudates enter the soil directly. These differences affect decomposition through moisture and temperature conditions, exposure to soil organisms, and degree of contact with mineral soil.

\section{Soil potential for carbon accumulation}

The amount of organic carbon stored in soil results from the net balance between the rate of soil organic carbon inputs and rate of mineralization in each of the organic 
carbon pools described above. Schlesinger (1990) compiled data on long-term rates of soil organic carbon accumulation in Holocene age soils. He found a slow rate of carbon increase in soil even after thousands of years. This long-term increase represents accumulations of passive soil organic carbon fractions, which include charcoal and resistant compounds physically protected in organomineral complexes. Schlesinger (1990) documented long-term rates of carbon storage from $0.2 \mathrm{~g}$ $\mathrm{C} \mathrm{m}^{-2} \mathrm{y}^{-1}$ in some polar deserts to greater than $10 \mathrm{~g}$ $\mathrm{C} \mathrm{m}^{-2} \mathrm{y}^{-1}$ in some forest ecosystems, with an average rate of $2.4 \mathrm{~g} \mathrm{C} \mathrm{m}^{-2} \mathrm{y}^{-1}$ over all ecosystems. Schlesinger (1990) indicates that faster rates of change over short time periods are possible as a result of changes in environmental conditions.

When natural vegetation is converted to cultivated crops, rapid declines in soil organic matter are due partly to a lower fraction of nonsoluble material in the more readily decomposed crop residues. Tillage, in addition to mixing and stirring of soil, breaks up aggregates and exposes organo-mineral surfaces otherwise inaccessible to decomposers. This results in a reduction in the amounts of intra-aggregate LF-OC and some organomineral SOC. Losses of SOC of as much as $50 \%$ in surface soils $(20 \mathrm{~cm})$ have been observed after cultivation for 30-50years. Reductions average around $30 \%$ of the original amount in the top 100-cm. The large and relatively rapid changes in SOC with cultivation indicates that there is considerable potential to enhance the rate of carbon sequestration in soil with management activities that reverse the effects of cultivation on SOC pools. The refilling of depleted fastturnover LC-OC pools and the active portions of the organomineral pools may result in much higher rates of SOC storage than the slow accumulation of passive soil carbon documented by Schlesinger (1990). Although the time period for high accumulation rates may be relatively short, years or decades, these accumulation rates are of significance for current soil sustainability and carbon management issues.

\section{Methods}

We collected the available literature that reports soil organic matter changes resulting from land conversion from cultivated to perennial vegetation. The information can be organized into two categories of land-use change (Tables 1 and 2). Table 1 reports rates of soil carbon change during forest or woody vegetation establishment after some period of agricultural use. Table 2 contains rates of soil carbon change after establishment of permanent pasture. For most studies, changes in SOC are estimated using paired plots. One or more plots were converted from agricultural use to forest or grassland, while adjacent plots or nearby plots with the same soil were treated as controls or initial conditions in calculating changes of organic soil carbon. At several sites, soil samples were collected periodically during forest growth and were used for making SOC measurements (Jenkinson 1971; Richter etal. 1994, 1999). All studies have measurements that represent changes in soil carbon content during at least one time interval. These are reported in the 'avg.' column and represent the average rate of change in soil carbon over the time interval computed by taking the total change in carbon amount and dividing by the number of years in the time interval. The actual rate of soil carbon change may or may not be constant over the time interval. Several studies estimated rates of SOC change for two or more time intervals. For these, the maximum rate of change over any time interval is reported in the 'max.' column. The time course of SOC accumulation for each plot with multiple measurement intervals reported is not presented. There is considerable variation and insufficient replication so that these time courses are not uniform. Presentation of the 'max.' rates allows some evaluation of whether most of the accumulation occurred over a relatively short period of time (max. much greater than avg.) or whether the accumulation was fairly constant over the entire measurement period (max. approximately the same as avg.). The maximum was often observed during the first measurement interval.

Soil bulk density measurements are required to calculate a carbon amount from studies that report only carbon or organic matter concentrations. For studies where bulk density measurements were absent, we estimated bulk density (BD) using the Adams (1973) equation:

$$
B D=\frac{100}{\frac{\% O M}{0.244}+\frac{100-\% O M}{M B D}},
$$

where OM is organic matter and MBD is mineral bulk density. Mineral particle density is usually assumed to be the specific gravity of quartz $\left(2.65 \mathrm{Mg} \mathrm{m}^{-3}\right)$. Actual MBD is considerably lower than rock bulk density since soil consists of irregularly shaped mineral particles that allow large voids between them. We used a typical value of 1.64 for MBD (Mann 1986). Soil depth was not adjusted to account for changes in bulk density unless the authors of the original data had already done so. Not adjusting soil depth may, in some cases, result in an underestimate of soil carbon gains.

\section{Results and discussion}

\section{Forest establishment after agricultural use}

Rates of SOC change under aggrading forest range from small losses under cool temperate-zone pine-dominated 
Table 1 Rates of soil carbon accumulating during forest establishment after agricultural use

Rate of $\mathrm{C}$ change $\left(\mathrm{g} \mathrm{m}^{-2} \mathrm{y}^{-1}\right)$

Site history

Years since Soil sample depth $(\mathrm{cm})$ max. avg

Reference

Cool temperate moist forest

Cultivated to pine plantation

Old field succession to northern hardwoods

Long-term agriculture to oak forest

Long-term agriculture to oak forest(P amended)

Old field succession to mixed oak stand

Old field succession to northern hardwoods

Old field to managed pine plantation

Abandoned field to mixed forest

Constructed dike to forest

$0-10$

$\begin{array}{cl}42-88 & 0-10 \\ 42-88 & 30-40 \\ 1-60 & 10 \\ 83 & 68.6 \\ 82 & 68.6 \\ >250 & 15.0 \\ >100 & 10.0 \\ 10-50 & 15.4 \\ 2-65.5 & 42.8 \\ 100 & 12 \\ & \end{array}$

Mine spoil to forest

\section{Harrison \#1}

Warren

Silver

Kinney

Warm temperate thorn steppe

Grazing exclusion - shrub live oak

Grazing exclusion - mountain mahogany

Grazing exclusion - shrubless openings

Warm temperate dry forest

New parent material to chaparral - oak

New parent material to chaparral - pine

New parent material to chaparral - chamise

New parent material to chaparral - ceanothus

Warm temperate moist forest

Old field to pine to hardwood succession

Old field to pine-natural succession

Old field to managed pine plantation

$\begin{aligned} & \approx 50 \\ & 50-70 \\ & 110 \\ & \approx 50 \\ & 70 \\ & 40\end{aligned}$

$\begin{array}{cc}-8.56 & -4.44 \\ -5.27 & -2.78 \\ 16.03 & 15.06 \\ 61.7 & 59.60 \\ 33.3 & 28.0 \\ 28.3 & 9.4 \\ 17.3 & 11.6 \\ & 65.66 \\ 23.9 & 2.15 \\ & 26.3\end{array}$

Pregitzer \& Palik (1996)

Zak et al. (1990)

Jenkinson (1971)

Jenkinson (1971)

Robertson \& Vitousek (1981)

Robertson \& Tiedje (1984)

Wilde (1964)

Hamburg (1984)

Beke (1990)

Leisman (1957)

Leisman (1957)

Leisman (1957)

Leisman (1957)

Brejda (1997)

Brejda (1997)

Brejda (1997)

Ulery (1995)

Ulery (1995)

Ulery (1995)

Ulery (1995)

Switzer et al. (1979)

Montes \& Christensen (1979)

Christensen \& MacAller (1985)

Christensen \& MacAller (1985)

Christensen \& MacAller (1985)

Schiffman \& Johnson (1989)

Hosner \& Graney (1970)

Billings (1938)

Schiffman \& Johnson (1989)

Coile (1940)

Richter et al. 1999 


\begin{tabular}{|c|c|c|c|c|c|}
\hline Site history & $\begin{array}{l}\text { Years since } \\
\text { agriculture }\end{array}$ & $\begin{array}{l}\text { Soil sample } \\
\text { depth }(\mathrm{cm})\end{array}$ & $\begin{array}{l}\text { Rate of C } \\
\text { max. }\end{array}$ & $\begin{array}{l}\left.\mathrm{g} \mathrm{m}^{-2} \mathrm{y}^{-1}\right) \\
\operatorname{avg}\end{array}$ & Reference \\
\hline \multicolumn{6}{|l|}{ Subtropical dry forest } \\
\hline Abandoned pasture & 25 & 38.1 & \multirow[t]{3}{*}{-20.36} & -13.08 & Smith et al. (1951) \\
\hline Long-term agriculture to secondary forest & 35 & 25.0 & & 80.0 & Brown \& Lugo (1990) \\
\hline Long-term agriculture to mahogany plantation & 50 & 25.0 & & 38.0 & Brown \& Lugo (1990) \\
\hline \multicolumn{6}{|l|}{ Subtropical moist forest } \\
\hline Long-term agriculture to secondary forest & 35 & 23.0 & \multirow{3}{*}{300.0} & 28.0 & Weaver et al. (1987) \\
\hline Long-term agriculture to secondary forest & 100 & 50.0 & & 105.0 & Brown \& Lugo (1990) \\
\hline Coffee plantation to abandoned coffee shade & 20 & 23.0 & & 99.0 & Weaver et al. (1987) \\
\hline Forest plantation with intensive site preparation & $2-34$ & 43.5 & 566.71 & -51.49 & Gholz \& Fisher (1982) \\
\hline \multicolumn{6}{|l|}{ Subtropical wet forest } \\
\hline 10-year-old crop fields to secondary forest & $38-47$ & 50.0 & \multirow[t]{4}{*}{566.7} & 148.8 & Brown \& Lugo (1990) \\
\hline Long-term agriculture to secondary forest & $\approx 35$ & 23.0 & & 98.7 & Weaver et al. (1987) \\
\hline 10-y-old crop fields to mahogany plantation & 51 & 50.0 & & 310.0 & Brown \& Lugo (1990) \\
\hline Coffee plantation to abandoned coffee shade & 30 & 23.0 & & 10.3 & Weaver et al. (1987) \\
\hline \multicolumn{6}{|l|}{ Tropical moist forest } \\
\hline Cultivated field to Eucalyptus plantation & 11.5 & 55 & & 12.17 & Bashkin et al. (1998) \\
\hline 1 year clearing to forest plantation & 10.5 & 100 & -1569.6 & -47.13 & Sanchez et al. 1985 \\
\hline Swidden agriculture (forest fallow period) & 10 & 10 & 143.3 & 68.9 & Aweto (1981) \\
\hline Short-term cropping to forest fallow & 50 & 40 & 740.0 & 61.2 & Ramakrishnan \& Toky (1981) \\
\hline \multicolumn{6}{|l|}{ Tropical wet forest } \\
\hline Primary succession (P1) & 126 & 1.5 & 3.36 & 1.18 & Vitousek et al. (1983) \\
\hline
\end{tabular}


Table 2 Rates of soil carbon accumulating during pasture establishment

\begin{tabular}{llll}
\hline Site history & $\begin{array}{l}\text { Years since } \\
\text { agriculture }\end{array}$ & $\begin{array}{l}\text { Soil sample } \\
\text { depth }(\mathrm{cm})\end{array}$ & $\begin{array}{l}\text { Rate of } \mathrm{C} \text { change }\left(\mathrm{g} \mathrm{m}^{-2} \mathrm{y}^{-1}\right) \\
\text { max. }\end{array}$ \\
\hline
\end{tabular}

Cool temperate steppe

Cultivated to perennial grass

Cultivated to abandoned field

Cultivated to seeded grass

Cultivated to improved pasture

Russian wildrye

crested wheatgrass

B-I-ALF(full)

B-I-ALF(short)

Mine tailing to grass-forb meadow

Coal mine spoil to dry grassland depth $(\mathrm{cm})$

(1)

Gebhart etal. (1994)

Subtropical moist forest

Cultivated to pasture

Atlantic

Caonilas

Culebrinas

North-west

(2) West

용 East

$\begin{array}{ll}\square & \text { South-east } \\ \stackrel{0}{2} & \text { South-west }\end{array}$

South

i Turabo

Tropical dry forest

Forest to unimproved pasture

Forest to improved pasture

Tropical moist forest

Native forest to pasture

300

$\begin{array}{rr}50 & 10 \\ 6 & 5\end{array}$

10
5

8

8

$5-80$

28-40

110.0

3.1
0.0

Burke et al. (1995)

Robles \& Burke (1998)

White etal. (1976)

6.86

18.87

14.01

60.0

34.15

7
10

10
120

4.01
28.2

Titlyanova et al. (1988)

Anderson (1977)

$-16.22$

$-48.65$

100.0

8.11

37.84

35.14

10.81

67.75

113.51

24.32

$-17.4$

$-13.0$

Trumbore et al. (1995)

Lugo et al. (1986)

Mature forest cleared to pasture Purto Velho

Calcaulandia

Nova Vida-1

Nova Vida-2

Ouro Preto-Benjamin

Ouro Preto-lenk

Vilhena

Purto Velho

$-30.0$

Trumbore et al. (1995)

83.18

$-4.02$

$342.72 \quad 15.23$

$174.81 \quad 24.10$

$\begin{array}{ll}115.54 & 39.27\end{array}$

$\begin{array}{ll}-84.13 & 2.37\end{array}$

$114.83 \quad 91.91$

$-14.29$

Neill et al. (1997) 


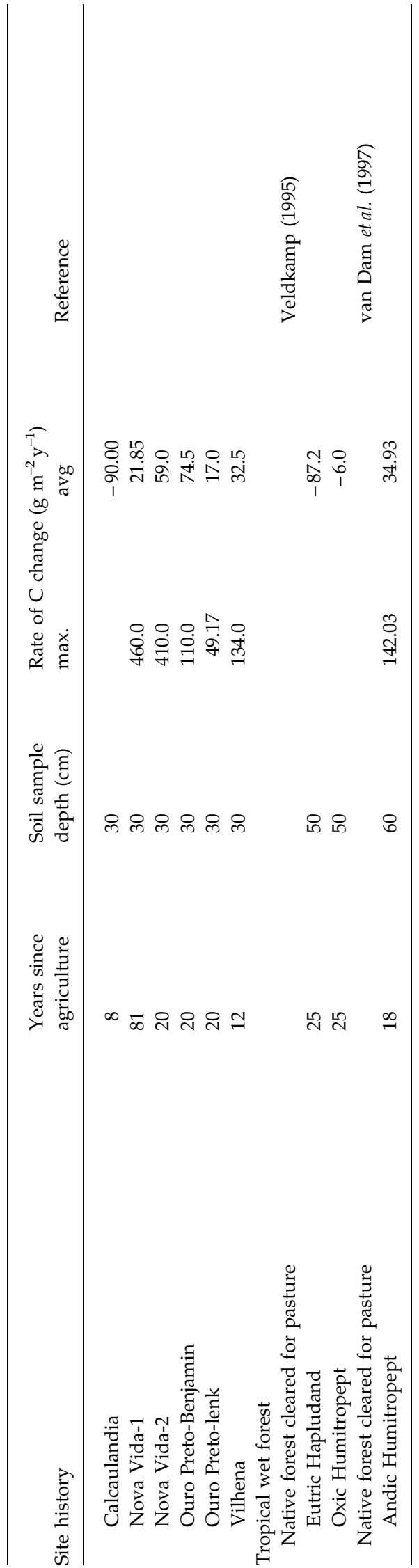

natural succession to an increase of $300 \mathrm{~g} \mathrm{C} \mathrm{m}^{-2} \mathrm{y}^{-1}$ in a subtropical wet forest plantation. In two sites large SOC losses were observed when subsequent organic carbon inputs during the early stages of forest growth were not large enough to replenish the decomposition losses. An average accumulation rate of soil carbon, including these two sites, is $33.8 \mathrm{~g} \mathrm{C} \mathrm{m}^{-2} \mathrm{y}^{-1}$. This is quite similar to the $30 \mathrm{~g} \mathrm{C} \mathrm{m}^{-2} \mathrm{y}^{-1}$ estimated by Schlesinger (1990) as the rate of SOC accumulation in 40- to 50-y-old soils. There is a tendency for rates of SOC accumulation to increase from temperate regions to subtropical regions (Table1). We infer from this trend that major factors determining the rate of accumulation are amounts of organic matter inputs which increase with temperature and moisture.

Brejda (1997) studied a subtropical thorn steppe system, where the vegetation was shifted from a grazed grassland to an ungrazed woodland. Growth of woody plants resulted in a decrease in SOC, despite the fact that woody plants produced a greater amount of more recalcitrant material. Woody plants may be less effective than perennial grasses in some environments at storing carbon in soil. Woody plants deposit a larger fraction of total inputs than both grasses and pastures on the surface where decomposition conditions are generally more favourable. This may be the case in this study since a site in a grass opening without woody shrubs showed a SOC increase when grazing was eliminated. Another example that indicates the significance of vertical placement of new carbon inputs is demonstrated in a wet tropical forest life zone where sugar cane fields were converted to fast-growing eucalyptus trees (Bashkin \& Binkley 1998). After 10-13 years, soil carbon increased under eucalyptus by $1150 \mathrm{~g} \mathrm{C} \mathrm{m}^{-2}$ in the top $10 \mathrm{~cm}$ of soil, but decreased by $1010 \mathrm{~g} \mathrm{Cm}^{-2}$ in the $10-55 \mathrm{~cm}$ layer. By examining changes in ${ }^{13} \mathrm{C}$ concentrations Bashkin \& Binkley (1998) were able to confirm that input rates of eucalyptus carbon into this deeper layer were small compared to previous sugar cane inputs.

There is considerable variation in accumulation rates of SOC in Table 1 that results from many factors and are not consistent among the studies. In addition to the differences in the quantity, quality and placement of organic carbon inputs mentioned above, there are differences in the degree to which labile soil organic carbon pools, particularly the LF-OC pools, were depleted by cultivation prior to abandonment or landuse conversion. The rate of decomposition is usually well represented as a first-order process where the amount of decomposition per unit time depends on the amount of material subject to decomposition times the rate constant for the environmental conditions and type of material. The amount of material in each decomposition class at the initial time in each study depends on the previous management history, which is generally unknown. As a 
result, initial decomposition amount may be low (SOC pools relatively depleted) or high (SOC pools large) relative to those that can be maintained if SOC pools were in equilibrium with current input rates of organic matter. When considering management activity to sequester carbon in soil, knowledge of site history such as cultivation duration is important. In two sites large SOC losses were observed. In both cases, the prior period of agricultural use or a bare fallow was short - only one year (Gholz \& Fisher 1982; Sanchez et al. 1985). In these cases, the short period of disturbance did not deplete the rapid turnover pools before forest planting.

In approximately half the studies that have multiple measurement intervals there is a large difference between the maximum and average accumulation (or loss) rate. This indicates a slowing in accumulation rate as new steady-state amounts of SOC are established and decomposition rates more closely match input rates. Some of these may be artefacts that arise from spatial heterogeneity and insufficient sampling. Additional errors arise with studies of chronosequences and paired plots. The cultivated plots may not have been in equilibrium and therefore lost additional SOC since paired perennial vegetation plots were established resulting in an overestimate of the initial rates of SOC accumulation. In two studies the max. rates greatly exceed the avg. ones (Gholz \& Fisher 1982; Sanchez et al. 1985). In both these studies site preparation and mixing of harvest residue into the soil greatly increased the amount of relatively undecomposed residue included in the first time interval measurements.

Many studies have similar max. and avg. rates of SOC accumulation. This indicates that there are conditions where accumulation rate may be fairly constant over periods as long as 50-100 years. The clearest examples are from the long-term plots at Rothamsted, England (Jenkinson 1971). These studies avoid most effects of spatial heterogeneity introduced by paired plot studies since samples were taken 3 times from the same plots over the first 80 years of the experiments. The soils at the beginning of the experiments, had been continuously cultivated since Roman occupation nearly 2000 years ago without any modern production enhancing amendments resulting in very low SOC amounts. The Broadbalk and Geescroft Wildernesses have shown constant rates of SOC accumulation, $60 \mathrm{~g} \mathrm{C} \mathrm{m}^{-2} \mathrm{y}^{-1}$ and $30 \mathrm{~g} \mathrm{C} \mathrm{m}^{-2} \mathrm{y}^{-1}$, respectively, for over 80 years since cultivation was halted and oak forest appeared through natural succession.

\section{Permanent grassland establishment}

Substantial gains in SOC are also possible with conversion of cropland to grassland, particularly with management for high grass productivity (Table2). A study of the grassland Conservation Reserve Program (CRP) for a productive portion of U.S. Central Plains (Texas, Kansas \& Nebraska, Gebhart et al. 1994) indicates that SOC may accumulate at an average rate of $110.0 \mathrm{~g} \mathrm{C} \mathrm{m}^{-2} \mathrm{y}^{-1}$ in the surface $300 \mathrm{~cm}$. These are probably maximum rates that will decline over time. Results from subtropical moist forest life zones demonstrate a potential for SOC gains when row crops are replaced with managed pasture (Lugo et al. 1986). The mean accumulation rate from this study is $33.2 \mathrm{~g} \mathrm{C} \mathrm{m}^{-2} \mathrm{y}^{-1}$. SOC accumulation rates are much lower under more arid conditions. White et al. (1976) found lower values in South Dakota - an average of $21 \mathrm{~g} \mathrm{C} \mathrm{m}^{-2} \mathrm{y}^{-1}$ - where the rates show considerable variation among plots with different species of plants established. In the shortgrass steppe of Colorado, Burke et al. (1995) found very low rates of SOC accumulation on unimproved abandoned crop fields. They report an accumulation rate of $3.1 \mathrm{~g} \mathrm{C} \mathrm{m}^{-2} \mathrm{y}^{-1}$ over a $50-\mathrm{y}$ period. The actual accumulation rate may even be lower if additional losses, including erosion of $\mathrm{C}$ from the paired cultivated fields over the last 50 years are taken into account. Robles \& Burke (1998) did not find significant soil carbon gains in CRP land soils 6 years following cessation of cultivation in a semiarid grassland (Wyoming), but they did find significant increases in mineralizable and coarse LF-OC. These facts suggest that longer time periods are required for pronounced increases in total SOC under conditions of low productivity.

SOC is likely to increase when cultivated soil is planted with permanent grasses. Conversion of woody vegetation to grasses may also affect SOC storage. Replacement of native tropical savanna with productive, deep-rooting exotic grasses (Fisher et al. 1994) can also result in significant SOC increases for several years (800$1300 \mathrm{~g} \mathrm{C} \mathrm{m}^{-2} \mathrm{y}^{-1}$ over the first $3-6$ years). When forest is cleared for pasture establishment, considerable aboveground carbon in vegetation is lost, but it is not necessary that there be declines in SOC. At least for tropical moist and wet forest life zones, it is also possible for SOC to increase when native mature forest is cleared and converted to pasture. In a study by Neil et al. (1997) 11 of 14 pasture conversion sites studied in Brazil showed increases in soil carbon. All sites in pasture for at least 10 years showed increases, with rates as high as $74.0 \mathrm{~g} \mathrm{C} \mathrm{m}^{-2} \mathrm{y}^{-1}$ over 20 years. Two out of three sites studied in Costa Rica found declines in SOC when native forest was cleared for pasture (Veldkamp 1994). However, on one rich volcanic soil with andic properties (soils with high activity clay minerals) conversion to pasture resulted in significant increases in SOC (Van Dam et al. 1997). Tropical dry forest showed decreases in SOC when converted to pasture (Trumbore et al. 1995) although site preparation methods complicate interpretation of the results in this study. 


\section{Conclusions}

There are many factors and processes that determine the direction and rate of change in SOC content when vegetation and soil management practices are changed. Ones that may be important for increasing SOC storage include: (i) increasing the input rates of organic matter; (ii) changing the decomposability of organic matter inputs that increase LF-OC (in particular); (iii) placing organic matter deeper in the soil either directly by increasing below-ground inputs or indirectly by enhancing surface mixing by soil organisms; and (iv) enhancing physical protection through either intra-aggregate or organomineral complexes. Conditions favouring these processes occur generally when soils are converted from cultivated use to permanent perennial vegetation. We observe variation in the rates of SOC change due to the differences in the influences of one or more of these factors even with data collected from similar studies. Additional variation in the data presented in Tables 1 and 2 can be attributed to a lack of consistent initial conditions resulting from differences in cultivation history and spatial heterogeneity.

To obtain a higher precision predictive capability of detecting changes in SOC, additional empirical studies are needed combined with a better understanding of the biological and physical processes involved. Long-term agricultural trials have been valuable for understanding soil carbon dynamics under agriculture (Jenkinson 1991). Additional long-term experiments that address SOC dynamics when land is converted from cultivation with known management histories to perennial vegetation would be valuable in improving our understanding and increase our predictive capability over short and long timescales.

While there are not enough data currently available to determine precisely the amount of carbon accumulating in any large region or even some particular plot of land, we have enough information to infer the order of magnitude of the soil carbon sequestration rate. We can use this information to investigate some aspects of soil carbon fluxes in the present global carbon cycle. Various investigations have inferred indirectly from atmospheric $\mathrm{CO}_{2}$ measurements that the terrestrial ecosystems of the Northern Hemisphere have been taking up and storing carbon in both vegetation and soil at a rate of $1-2 \mathrm{Pg}$ $\mathrm{C}^{-1} \mathrm{y}^{-1}\left(1 \mathrm{Pg}=10^{15} \mathrm{~g}\right)$ over the past several decades (Tans etal. 1990; Ciais etal. 1995; Fan etal. 1998). Various hypotheses have been proposed concerning the processes involved and regions where various processes may have greater or lesser effects on the rate of net carbon uptake. One hypothesis that the information presented here can address is that the inferred northern hemisphere terrestrial sink is related to land-use change over the past 50 years. Hart (1968) reported that over the 1950s $27 \times 10^{6}$ ha of farmland was abandoned in the eastern United States. The amount of land in the U.S. reforested or afforested in the 1980s is reported in Winjum etal. (1990) as $12 \times 10^{6}$ ha. Taking the larger rate of land-use change reported by Hart (1968), and assuming that this continued from 1950 to present, there is a cumulative potential of $135 \times 10^{6}$ ha that support aggrading forest. Applying the average rate of SOC accumulation to this entire area, the present rate of SOC sequestration would be $0.05 \mathrm{PgCy}^{-1}$. Only a small fraction of the inferred northern hemisphere terrestrial sink can be explained in terms of SOC accumulations in aggrading forests of the U.S. King et al. (1990) indicate that $154 \times 10^{6}$ ha $\left(120 \times 10^{6}\right.$ ha in China and India alone $)$ were reforested or afforested in the Northern Hemisphere in the 1980s. Assuming that all this land was afforested and not just replanted after a harvest, and that this rate continued through the 1990s, then the rate of SOC accumulation would potentially be $0.11 \mathrm{PgCy}^{-1}$. While not insignificant, this rate is a very small fraction of the estimated rate of carbon sequestration in the Northern Hemisphere. If $1-2 \mathrm{PgCy}^{-1}$ are currently accumulating in aggrading forests then nearly all of this $\mathrm{C}$ would be increases in biomass and surface litter, not SOC.

\section{Acknowledgements}

Research sponsored by the U.S. Department of Energy, Carbon Dioxide Research Program, Environmental Sciences Division, Office of Biological and Environmental Research, under contract DE-AC05-96OR22464 with Lockheed Martin Energy Research Corp. We thank Anthony King, Robert Luxmoore, Steve Pacala, and 2 anonymous reviewers for suggestions that lead to clarifications of various aspects in an earlier version of the manuscript.

\section{References}

Adams WA (1973) The effect of organic matter on the bulk and true densities of some uncultivated podzolic soils. Journal of Soil Science, 24, 10-17.

Anderson DW (1977) Early stages of soil formation on glacial till mine spoils in a semi-arid climate. Geoderma, 19, 11-19.

Aweto AO (1981) Secondary succession and soil fertility restoration in south-western Nigeria. II. Soil Fertility Restoration. Journal of Ecology, 69, 609-614.

Bashkin MA, Binkley D (1998) Changes in soil carbon following afforestation in Hawaii. Ecology, 79, 828-833.

Beare MH, Cabrera ML, Hendrix PF, Coleman DC (1994) Aggregate-protected and unprotected organic matter pools in conventional- and no-tillage soils. Soil Science Society of America Journal, 58, 787-795.

Beke GJ (1990) Soil development in a 100-year-old dike near Grand Pr\#233, Nova Scotia. Canadian Journal of Soil Science, 70, 683-692. 
Biederbeck VO, Janzen HH, Campbell CA, Zentner RP (1994) Labile soil organic matter as influenced by cropping practices in an arid environment. Soil Biology and Biochemistry, 26, 16471656.

Billings WD (1938) The structure and development of old field shortleaf pine stands and certain associated physical properties of the Soil. Ecological Monographs, 8, 437-499.

Boone RD (1994) Light-fraction soil organic matter: origin and contribution to net nitrogen mineralization. Soil Biology and Biochemistry, 26, 1459-1468.

Brejda JJ (1997) Soil changes following 18 years of protection from grazing in Arizona chaparral. The Southwestern Naturalist, 42, 478-487.

Bremer E, Janzen HH, Johnston AM (1994) Sensitivity of total, light fraction and mineralizable organic matter on management practices in a Lethbridge soil. Canadian Journal of Soil Science, 74, 131-138.

Brown S, Lugo AE (1990) Effects of forest clearing and succession on the carbon and nitrogen content of soils in Puerto Rico and US Virgin Islands. Plant and Soil, 124, 53-64.

Burke IC, Lauenroth WK, Coffin DP (1995) Soil organic matter recovery in semiarid grasslands: implications for the conservation reserve program. Ecological Monographs, 5, 793-801.

Buyanovsky GA, Aslam M, Wagner GH (1994) Carbon turnover in soil physical fractions. Soil Science Society of America Journal, 58, 1167-1173.

Cambardella CA, Elliot ET (1992) Particulate soil organic-matter changes across a grassland cultivation sequence. Soil Science Society of America Journal, 56, 777-783.

Cambardella CA, Elliot ET (1993) Carbon and nitrogen distribution in aggregates from cultivated and native grassland soils. Soil Science Society of America Journal, 57, 1071-1076.

Christensen NL, MacAller T (1985) Soil mineral nitrogen transformations during succession in the Piedmont of North Carolina. Soil Biology and Biochemistry, 17, 675-681.

Christensen BT (1992) Physical fractionation of soil and organic matter in primary particle size and density separates. Advances in Soil Science, 20, 1-90.

Christensen BT (1996) Matching measurable soil organic matter fractions with conceptual pools in simulation models of carbon turnover: Revision of model structure. In: Evaluation of Soil Organic Matter Models (eds Powlson DS et al.), NATO ASI Series 1, Vol 38. Springer, Berlin.

Ciais P, Tans PP, White JWC et al. (1995) Partitioning of ocean and land uptake of $\mathrm{CO}_{2}$ as inferred by $\delta^{13} \mathrm{C}$ measurements from the NOAA Climate Monitoring and Diagnostics Laboratory global air sampling network. Journal of Geophysical Research, 100, 5051-5070.

Coile TS (1940) Soil Changes Associated with Loblolly Pine Succession on Abandoned Agricultural Land of the Piedmont Plateau, School of Forestry Bulletin 5. Duke University, Durham, NC.

Davidson EA, Ackerman IL (1993) Changes in soil carbon inventories following cultivation of previously untilled soils. Biogeochemistry, 20, 161-193.

Desjardins T, Andreux F, Volkoff B, Cerri CC (1994) Organic carbon and ${ }^{13} \mathrm{C}$ contents in soils and soil size-fractions, and their changes due to deforestation and pasture installation in eastern Amazonia. Geoderma, 61, 103-118.

Elliott ET, Cambardella CA (1991) Physical separation of soil organic matter. Agriculture, Ecosystems and Environment, 34, 407-419.

Fan S, Gloor M, Mahlman J, Pacala S, Sarmiento J, Takahashi T, Tans P (1998) A Large Terrestrial Carbon Sink in North America Implied by Atmospheric and Oceanic Carbon Dioxide Data and Models. Science, 282, 442-446.

Fisher MJ, Rao IM, Ayarza MA et al. (1994) Carbon storage by introduced deep-rooted grasses in the South American savannas. Science, 371, 236-238.

Gebhart DL, Johnson HB, Mayeux HS, Polley HW (1994) The CRP increases in soil organic carbon. Journal of Soil and Water Conservation, 49, 488-492.

Gholz HL, Fisher RF (1982) Organic matter production and distribution in slash pine (Pinus elliottii) plantations. Ecology, 63, 1827-1839.

Hamburg SP (1984) Effects of forest growth on soil nitrogen and organic matter pools following release from subsistence agriculture. In: Forest Soils and Treatment Impacts (ed. Stone EL), Proceedings of the Sixth North American Forest Soils Conference, pp. 145-158. University of Tennessee, Knoxville. Harrison KG, Broecker WS, Bonani G (1993) The effect of changing land use on soil radiocarbon. Science, 262, 725-726.

Hart JF (1968) Loss and abandonment of cleared farm land in the eastern United States. Annals of the Association of American Geographers, 58, 417-440.

Hosner JF, Graney DL (1970) The relative growth of three forest tree species on soils associated with different successional stages in Virginia. The American Midland Naturalist, 84, 418427.

Jenkinson DS (1971) The accumulation of organic matter in soil left uncultivated. Report Rothamsted Experimental Station for 1970, Part 2, pp. 113-137.

Jenkinson DS (1990) The turnover of organic carbon and nitrogen in soil. Philosophical Transactions of the Royal Society of London B, 329, 361-368.

Jenkinson DS (1991) The Rothamsted long-term experiments: are they still of use? Agronomy Journal, 83, 2-10.

Jenny H (1941) Factors of Soil Formation. McGraw-Hill, New York.

King GK, Winjum JK, Dixon RK, Arnout LY (1990) Response and Feedbacks of Forest Systems to Global Climate Change. EPA/600/ 3-90/080, Environmental Protection Agency, Corvallis, OR.

Leisman GA (1957) A vegetation and soil chronosequence on the Mesabi iron range soil banks, Minnesota. Ecological Monographs, 27, 221-245.

Lugo AE, Sanchez MJ, Brown S (1986) Land use and organic carbon content of some subtropical soils. Plant and Soil, 96, 185-197.

Mann LK (1986) Changes in soil carbon after cultivation. Soil Science, 142, 279-288.

Montes RA, Christensen NL (1979) Nitrification and succession in the Piedmont of North Carolina. Forest Science, 25, 287-297.

Neil C, Melillo JM, Seudler PA, Cerrl CC (1997) Soil carbon and nitrogen stocks following forest clearing for pasture in the southwestern Brazilian Amazon. Ecological Applications, 7, 1216-1225.

Oades JM (1993) The role of biology in the formation, stabilization and degradation of soil Structure. Geoderma, 56, 377-400

Parton WJ, Stewart JWB, Cole CV (1988) Dynamics of C, N, P and $S$ in grassland soils: a Model. Biogeochemistry, 5, 109-131. 
Post WM, Mann LK (1990) Changes in soil organic carbon and nitrogen as a result of cultivation. In: Soils and the Greenhouse Effect (ed. Bouwman AF), pp. 401-406. John Wiley, New York.

Pregitzer KS, Palik BJ (1996) Changes in ecosystem carbon 46 years after establishing red pine (Pinus Resinosa Ait) on abandoned agriculture Land in the Great Lakes Region. In Soil Organic Matter in Temperate Agroecosystems: Long-Term Experiments in North America (eds Paul EA et al.), pp. 263270. CRC Press, Boca Raton, FL.

Ramakrishnan PS, Toky OP (1981) Soil nutrient status of hill agro-ecosystems and recovery pattern after slash and burn agriculture (JHUM) in North-Eastern India. Plant and Soil, 60, 41-64.

Richter DD, Markewitz D, Wells CG, Allen HL, April R, Heine PR, Urrego B (1994) Soil chemical change during three decades in an old-field loblolly pine (Pinus taeda L.) ecosystem. Ecology, 75, 1463-1473.

Richter DD, Markewitz D, Trumbore SE, Wells CG (1999) Rapid accumulation and turnover of soil carbon in a re-establishing forest. Nature, 400, 56-58.

Robertson GP, Vitousek PM (1981) Nitrification potentials in primary and secondary succession. Ecology, 62, 376-386.

Robertson GP, Tiedje JM (1984) Denitrification and nitrous oxide production in successional and old-growth Michigan forests. Soil Science Society of America Journal, 48, 383-388.

Robles MD, Burke IC (1998) Soil organic matter recovery on Conservation Reserve Program fields in Southeastern Wyoming. Journal of the Soil Science Society of America, 62, 725-730.

Sanchez PA, Palm CA, Davey CB, Szott LT, Russell CE (1985) Tree crops as soil improvers in the humid tropics?. In: Trees as Crop Plants (eds Cannell MGR, Jackson JE), pp. 327-358. Institute of Terrestrial Ecology, Natural Environment Research Council, Edinburgh, UK.

Schiffman PM, Johnson WC (1989) Phytomass and detrital carbon storage during forest regrowth in the Southeastern United States Piedmont. Canadian Journal of For Research, 19, 69-78.

Schlesinger WH (1985) Changes in soil carbon storage and associated properties with Disturbance and recovery. In: The Changing Carbon Cycle: a Global Analysis (eds Trabalka JR, Reichle DE), Springer, New York.

Schlesinger WH (1990) Evidence from chronosequence studies for a low carbon-storage potential of soils. Nature, 348, 232 234.

Skjemstad JO, LeFeuvre RP, Prebble RE (1990) Turnover of soil organic matter under pasture as determined by ${ }^{13} \mathrm{C}$ natural abundance. Australian Journal of Soil Research, 28, 267-276.

Smith RM, Samuels G, Cernuda CF (1951) Organic matter and nitrogen build-ups in some Puerto Rican soil profiles. Soil Science, 72, 400-427.

Spycher G, Sollins P, Rose S (1983) Carbon and nitrogen in the light fraction of a forest soil: Verticle distribution and seasonal patterns. Soil Science, 135, 79-87.

Switzer GL, Shelton MG (1979) Successional development of the forest floor and soil surface on upland sites of the east gulf coastal plain. Ecology, 60, 1162-1171.

Tans PP, Fung IY, Takahaski T (1990) Observational constraints on the global atmospheric $\mathrm{CO}_{2}$ budget. Science, 247, 14311438.

Titlyanova AA, Mironycheva-Tokareva NP, Naumova NB (1988) Carbon cycle in grass ecosystems during overgrowth of spoil heaps. Pochvovedeniye, 7, 164-174 (translated into English).

Trumbore SE, Davidson EA, de Camargo PB, Nepstad DC, Martinelli LA (1995) Belowground cycling of carbon in forests and pastures of Eastern Amazonia. Global Biogeochemical Cycles, 9, 515-528.

Ulery AL (1995) Decade-scale changes of soil carbon, nitrogen and exchangeable cations under chaparral and pine. Geoderma, 65, 121-134.

Van Dam DV, Veldkamp E, Breemen N (1997) Soil organic carbon dynamics: variability with depth in forested and deforested soils under pasture in Costa Rica. Biogeochemistry, 39, 343-375.

Veldkamp D (1994) Organic carbon turnover in three tropical soils under pasture after Deforestation. Soil Science Society of America Journal, 58, 175-180.

Vitousek PM, Cleve KV, Balakrishman N, Dieter M-D (1983) Soil development and nitrogen turnover in Montane Rainforest on Hawaii. Biotropica, 15, 268-274.

Weaver PL, Birdsey RA, Lugo AE (1987) Soil organic matter in secondary forests of Puerto Rico. Biotropica, 19, 17-23.

White EM, Krueger CR, Moore RA (1976) Changes in Total N, Organic matter, available $\mathrm{P}$, and bulk densities of a cultivated soil 8 years after tame pastures were established. Agronomy Journal, 68, 581-583.

Wilde SA (1964) Changes in soil productivity induced by pine plantations. Soil Science, 97, 276-278.

Winjum JK, Schroeder PE, Mattson KG, King GA (1990) Mitigation of global change impacts through forest management. In: Response and Feedbacks of Forest Systems to Global Climate Change (eds King GA et al.), EPA/600/3-90/080. United States Environmental Protection Agency, Corvallis, OR.

Zak DR, Grugal DF, Gleeson S, Tilman D (1990) Carbon and nitrogen cycling during old-field succession: Constraints on plant and microbial biomass. Biogeochemistry, 11, 111-129. 